\title{
WALORY ARTYSTYCZNE I TREŚCI IKONOGRAFICZNE KOŚCIOLA I KLASZTORU BERNARDYNÓW W KRAKOWIE
}

Kościół i klasztor Bernardynów w Krakowie oraz zgromadzone tam zabytki z zakresu wyposażenia wnętrz, malarstwa, rzeźby, złotnictwa i haftów posiadają liczne opracowania. Można zaryzykować twierdzenie, że najczęściej zajmowano się znajdującymi się tutaj obrazami wybitnego malarza bernardyńskiego - Franciszka Lekszyckiego.

Syntetyczne omówienia kościoła i klasztoru Bernardynów w szerszym rozumieniu tego słowa istnieją właściwie tylko dwa. Pierwsze, to wydana jeszcze przed wojna, wspólna praca Kamila Kantaka, Jerzego Szablowskiego i Jerzego Żarneckiego; w książce tej nie omówiono tkanin i malarstwa miniaturowego. Jako drugie tego rodzaju opracowanie, szersze pod względem wymienionych zabytków uważać można wydany w 1987 roku Katalog Zabytków Miasta Krakowa, Kościoły i klasztory. Kazimierz i Stradom 1, pod redakcja Izabelli Rejduch-Samkowej i piszącego te słowa. W wymienionym Katalogu omówiono wszystkie udostępnione w kościele, zakrystii i klasztorze obiekty obficie ilustrując je fotografiami, których została opublikowana znaczna ilość - przeważnie po raz pierwszy.

Posiłkując się doświadczeniami nabytymi w czasie prac nad Katalogiem Zabytków, malarzem Franciszkiem Lekszyckim i złotnictwem w zbiorach bernardyńskich zajmiemy się najważniejszymi zjawiskami artystycznymi i tematami ikonograficznymi, jakie występują w kościele i klasztorze Bernardynów w Krakowie.

\section{ZABYTKI ŚREDNIOWIECZNE}

\section{Architektura}

Mówiąc o zabytkach średniowiecznych u Bernardynów zacząć należałoby od architektury. Niestety jak kiedyś napisał ksiądz Kamil Kantak: „Nie doszły nas żadne wiadomości o pierwotnym wyglądzie kościoła i klasztoru". Ze swojej strony pragnę dodać, że nie są mi też wiadome informacje o żadnych pracach badawczych dotyczących architektury gotyckiego kościoła Bernardynów. Widok Vischera - Meriana z początku XVII wieku wskazuje, że 
była to duża budowla $\mathrm{z}$ wieloboczną wieżą od frontu (wcześniej kościół miał wieże „szachulcową"). W czasie prac nad redakcją Katalogu Zabytthów uzy= skaliśmy na miejscu ustną wiadomość, że w czasie remontu w ścianie między zakrystia a prezbiterium natrafiono na zniszczone pożarem partie murowane i drewniane.

\section{Rzeźba}

W kościele i klasztorze Bernardynów zachowało się niewiele obiektów rzeźby gotyckiej, ale mają one wyjątkową wartość artystyczną. Wymienić tu należy przede wszystkim datowaną na koniec XV wieku grupę św. Anny Samotrzeciej, umieszczona, co warto podkreślić, w osiemnastowiecznym ołtarzu Św. Anny, w kaplicy przylegającej do lewego ramienia transeptu. Jest to rzeźba wiazzana albo bezpośrednio $\mathrm{z}$ mistrzem Witem Stwoszem, albo też z jego najbliższym kręgiem i uważa się ją za jeden $\mathrm{z}$ najcenniejszych posagów o tej ikonografii w Polsce południowej. Kolejne dzieło gotyckiej rzeźby to przedstawienie głowy św. Jana na misie, datowane także na koniec XV wieku, które uchodzi za import lub wyrób lokalny, co jest bardziej prawdopodobne. Warto też przypomnieć, że przedstawienia o takiej samej ikonografii wykuwano z kamienia (zworniki sklepień) lub robiono ze srebra i kameryzowano (np. skarbiec katedry wrocławskiej). W Krakowie rzeźbiona głowa św. Jana na misie, ale późniejsza z XVI wieku znajduje się w zwieńczeniu jednego z ołtarzy bocznych w kościele ŚŚ. Jana Chrzciciela i Ewangelisty - Prezentek.

Zachowała się także w klasztorze Bernardynów pełna wyrazu późnogotycka rzeźba Chrystusa Frasobliwego - temat znany z innych kościołów Krakowa (Franciszkanów i Św. Krzyża).

\section{Malarstwo}

W krakowskim kościele i klasztorze Bernardynów nie zachowały się dzieła gotyckiego malarstwa tablicowego. Dotrwały jednak liczne rękopisy iluminowane, częściowo pochodzące z konwentu lwowskiego, w części przekazane do klasztoru w Leżajsku. Wiadomo, że w Krakowie u Bernardynów istniała pracownia iluminatorska. Wspomniany zbiór, to jeden $\mathrm{z}$ najcenniejszych, ze znajdujących się w mieście.

Najwcześniejsze książki iluminowane, mianowicie graduały, pochodzą $\mathrm{z}$ czasów po roku 1454, najpóźniejsze, często tradycyjne w wykonaniu, z 2 poł. XVIII wieku. Są to niekiedy dzieła autoryzowane, prace Józefa z Tyśmienicy z około roku 1525, czy Ambrożego z Zagórza z 1620 roku. Dodajmy, że poza graduałami dotrwały antyfonarze, psałterze, kancjonały i inne księgi. Mimo uszkodzeń zdobi je wiele niezwykle cennych miniatur, niektóre $\mathrm{z}$ nich pozostają $\mathrm{w}$ związku z małopolskim malarstwem sztalugowym. Chcielibyśmy zwrócić uwagę, ze względu na słabe zainteresowanie historyków sztuki na księgi ozdobione iluminacjami, pochodzące z XVII i XVIII wieku. Wielką wartość artystyczną posiadają też oprawy tłoczone w skórze z mosiężnymi okuciami, które pochodzą z czasu od XV do XVIII wieku. 


\section{Architektura}

Obecny kościół Św. Bernarda ze Sieny w Krakowie powstał w latach między 1659 a 1680 . Projektantem był wyróżniający się architekt Krzysztof Mieroszewski, który studiował w Bolonii. Mieroszewski pracował także przy fortyfikacjach w Krakowie i Częstochowie.

Kościół Bernardynów jest trzynawową bazylika $\mathrm{z}$ transeptem $\mathrm{i}$ dwiema kaplicami: Św. Anny i Błogosławionego Szymona z Lipnicy, przy długim, prostokątnym prezbiterium. W architekturze barokowej już budowli zwracaja uwage cztery elementy, są nimi: fasada, kopuła, chór muzyczny i dekoracja wnętrza.

Fasada świątyni należy do rzadkiego w Krakowie typu elewacji frontowych trójkondygnacjowych. Środkowe jej piętro jest węższe od pozostałych, główny zaś portal jest stosunkowo niewielki, co wskazuje, można powiedzieć, na użycie w krakowskich budowlach $z 2$ poł. XVII wieku manierystycznych tradycji. Wieże kościoła, co jest zaskakującym zjawiskiem nawiązują do ośmiobocznych wież romańskiego kościoła Św. Andrzeja, w ten sposób uzyskano wyjątkowy efekt urbanistyczny. Inny natomiast problem nasuwa kopuła znajdująca się w krzyżu kościoła Bernardynów. Jest ona ukryta, na zewnątrz widzimy tylko latarnię z kopułką. Takie rozwiązanie zostało podyktowane względami obronności zamku na Wawelu; chodziło o to, aby $\mathrm{z}$ wyniosłej kopuły nieprzyjaciel nie miał możliwości ostrzeliwania zamku. Takie rozporządzenie obowiazywało mamy tu na myśli ograniczenie wysokości przy budowie kościoła i klasztoru.

Inne problemy nasuwa do przemyślenia murowany kolumnowy chór muzyczny w kościele Bernardynów w kształcie tradycyjnej logii. Jest to najpóźniejsze w charakterystycznych dla manieryzmu i baroku krakowskich rozwiązań, które znamy m.in. z kościoła Dominikanek na Gródku, kaplicy Batorego przy katedrze na Wawelu, u Franciszkanów - niezachowany, zastapiony neogotyckim, z bóżnicy Izaaka (Ajzyka) na Kazimierzu (w bóżnicy rozwiązanie podobne do chórów w kościołach katolickich przeznaczone jest dla kobiet). Chóry te powstałe w epoce baroku jak i krużganki w budowlach uniwersyteckich, pałacach i kamienicach Krakowa sa dowodem na to jak długo żyły w Krakowie koncepcje architektoniczne w duchu manieryzmu.

Nieco uwag nasuwa też stiukowa dekoracja wnętrza kościoła, która ozdobiono także obszerny refektarz klasztorny. Jest to typowa dla sakralnych wnętrz (kościoły, klasztory i bóżnica Ajzyka oraz sienie kamienic krakowskich) dekoracja geometryczna $\mathrm{z}$ profilowanych listew. Występuje ona od początku XVII wieku do początku XVIII stulecia i ma właściwie charakter na tyle manierystyczny, co i barokowy.

Bernardyńskie stiuki należą jednak do najbogatszych w Krakowie. Godnymi uwagi są rozety w podłuczach arkad międzynawowych, mające renesansowy rodowód. 


\section{Wyposażenie wnętrza i rzeźba}

Wyposażenie wnętrza w kościele Bernardynów należy do najbogatszych w Krakowie. Składa się nań aż piętnaście ołtarzy o bogatej dekoracji figuralnej i ornamentalnej, ambona, organy i ławki, które zostaną osobno omówione.

Retabula te pochodzą $\mathrm{z}$ dwóch okresów: $\mathrm{w}$ prezbiterium i transepcie z 2 poł. XVII wieku pod kopuła, i w nawie z XVIII stulecia. W późnobarokowym wyposażeniu dokonano pewne zmiany. W roku 1928 - wymieniono „Zwierciadlane” kolumny wykonane przez „Banarczyków” na kręcone. Mimo tych zmian jako całość ołtarze w kościele Bernardynów w Krakowie dzięki kulisowemu ustawieniu tworzą swoiste barokowe teatrum. Dodajmy, że w XVIII wieku czynni byli tu w latach 1758-1766 snycerze Michał Dobek (Dobkowski), Wojciech (?) Rojowski, zaś przy głównym ołtarzu stolarze: Sebastian Lagowski i brat Piotr Binder.

Dzieła stolarstwa i snycerstwa w kościele Bernardynów mówią o walorach na ogół niedocenianych krakowskich wyrobach z epoki późnego baroku. Prace te ustępują wprawdzie lwowskim oraz może warszawskim, ale posiadają własny lokalny charakter wywodzący się od nawiązywania do sztuki włoskiej warsztatu Baltazara Fontany. Niestety późnobarokowe stolarstwo i snycerstwo krakowskie $\mathrm{z}$ połowy XVIII wieku nie posiada osobnego monograficznego opracowania.

\section{Rzeźba nagrobkowa}

W kościele Bernardynów w Krakowie znajduje się ponad trzydzieści nagrobków i epitafiów z XVII, XVIII i XIX wieku. Nie wszystkie one były jednak fundowane do tej światyni; część pochodzi z gruntownie przebudowanego kościoła Karmelitów pw. ŚŚ. Michała i Józefa w Krakowie. Z nagrobków a właściwie części nagrobków najwcześniejszy jest według ostatnich badań pomnik bł. Szymona z Lipnicy, który posiada już nowe niewielkie monograficzne omówienie. $Z$ innych pomników na uwagę zasługują płyty z nagrobków Ługowskich - właścicieli podkrakowskiej Korzkwi: Stanisława (zm. 1612) i jego żony Zofii z Gołuchowskich (zm. 1595) fundacji syna Aleksandra. Jest dość późny przykład nagrobków z leżącymi postaciami zmarłych.

Epitafia u Bernardynów wyróżniają się bogatymi obramieniami z motywami śmierci a wykonane są najczęściej z czarnego marmuru dębnickiego. Dzięki nim kościół posiada jeden $\mathrm{z}$ największych w Krakowie zespołów pomników z tego materiału, do którego dodać jeszcze należy ołtarz i sarkofag w kaplicy błogosławionego Szymona z Lipnicy z rytą dekoracją z końca XVII wieku wykonaną przez Jacka Zielaskiego.

\section{Malarstwo}

W kościele i klasztorze Bernardynów znajduje się znaczna liczba dzieł malarstwa. Część obrazów przeniesiona została do muzeum prowincji Bernardynów w Leżajsku. 
Za najważniejsze malowidła uważa się cztery obrazy Bernardyna Franciszka Lekszyckiego z lat około 1659-1664. Sa to ołtarzowe malowidła przedstawiajace Ostatnią wieczerzę, Upadek pod krzyżem, Ukrzyżowanie i świętego Antoniego, głównie według rycin Boetiusa i Bolswerta. Dodajmy, że jest to największa i najpiękniejsza grupa obrazów Franciszka Lekszyckiego. Malarz ten posiada wiele większych i mniejszych omówień, sam kilkakrotnie o nim pisałem. Dotychczas jednak nie został dogłębnie zanalizowany manierystyczny koloryt obrazów Lekszyckiego, oczywiście odmienny od kolorystyki Rubensa, będący specyficzną wartością malarstwa mistrza Franciszka, na co kilkakrotnie zwracałem uwagę.

Ogólnie znanym obrazem z kościoła Bernardynów jest duże malowidło „Taniec śmierci”. Obraz ten jest także często wzmiankowany, dotąd brak jednak szczegółowej analizy kostiumologicznej, która pozwoliłaby na dokładniejsze zadatowanie malowidła. Szczególną wartość historyczną posiadają portrety zachowane w klasztorze Bernardynów, pochodzące głównie z XVIII wieku. Godne zainteresowania są wizerunki papieży: Piusa V - papieża w latach 1566-1572, Innocentego XIII - papieża z lat 1721-1724. Dodajmy, że zespół portretów papieży zachował się też w Krakowie w klasztorze Klarysek przy kościele Św. Andrzeja oraz u Dominikanów.

\section{Zlotnictwo}

Dzieł złotniczych zachowało się w klasztorze Bernardynów w Krakowie kilkadziesiąt. Sa to monstrancje (ostatnio osobno omówione) kielichy, relikwiarze i vota - wymieniając najważniejsze rodzaje zabytków. Zachowane obiekty to w przeważającej mierze krakowskie prace cechowe, być może niektóre wyroby powstały w warsztatach klasztornych. Trudno wskazać tu dzieła wyróżniające się wybitną wartością artystyczna. Ta ostatnia jest zazwyczaj dobra, czasem przeciętna. Zachowane obiekty pochodza od XVII do XX stulecia włącznie. Niewatpliwie pośród relikwiarzy najciekawszym dziełem złotnictwa jest puszka na głowę błogosławionego Szymona z Lipnicy. Relikwiarz ten należy do typu wielobocznych puszek przykrytych kopułka z wziernikiem, popularnego w sztuce polskiej głównie w Małopolsce i Wielkopolsce od XV do XIX wieku. Relikwiarz bernardyński zdobi osiem scen z życia błogosławionego, które stanowią największy plastycznie wykonany cykl dotyczący błogosławionego Szymona.

$\mathrm{Z}$ innych zupełnie niezbadanych obiektów chciałbym wymienić oryginalnie skomponowany relikwiarz błogosławionego Władysława z Gielniowa, wykonany w Krakowie w roku 1899 przez J. Grzegorczyka (artysty tego, zapewne odlewnika, nie wymienia ani Leonard Lepszy, ani Feliks Kiryk). Relikwiarz daje cenne informacje jak wyglądały prace neogotyckie około roku 1900 . 


\section{Tkaniny i hafty}

Szaty liturgiczne

W klasztorze Bernardynów w Krakowie zachowała się znaczna liczba szat liturgicznych. Są to oczywiście kapy, ornaty, dalmatyki, czasem całe garnitury $\mathrm{i}$ inne paramenty. Wykonano je $\mathrm{z}$ tkanin (przeważnie boki ornatów) i haftów. O ile tkaniny są importami, jak to zazwyczaj ma miejsce w polskich skarbcach - z Włoch i Francji, hafty są lokalnymi wyrobami; niestety jak, niemal zawsze nie da się ustalić ich autorstwa. Przypomnijmy, że hafty polskie, znane od średniowiecza, wykonywane były w klasztorach, miejskich warsztatach cechowych, na dworach królewskich, magnackich i szlacheckich.

Zbiór u Bernardynów w swoim charakterze jest dość typowym zespołem tkanin i haftów zachowanych w Krakowie, których jest wiele tysięcy. Niestety okres najbogatszy, czyli czasy baroku w odniesieniu do tych zabytków, są w minimalnym stopniu opracowane. O ile potrafimy datować tego rodzaju obiekty $\mathrm{z}$ czasów baroku, o tyle co jest swoistym paradoksem trudno niekiedy określić czas powstania haftowanych ornatów z zaawansowanych lat XIX wieku.

\section{Watki ikonograficzne}

Tematy ikonograficzne zrealizowane w rzeźbie, malarstwie i rzemiośle artystycznym zbiorów bernardyńskich, nie były, co warto podkreślić, dotąd przedmiotem osobnych badań.

Na pierwszy plan wysuwa się tematyka zakonna - bernardyńska i związana z nią franciszkańska. Przypomnijmy, że trzy największe i najważniejsze obrazy w kościele dotyczą męki Chrystusa; nie brak też otoczonych kultem przedstawień Św. Antoniego, Franciszka, Jana Kapistrana, błogosławionego Szymona z Lipnicy i innych postaci głównie z kręgu błogosławionych i świętych zasłużonych dla klasztoru. Pragnę jednak podkreślić, że tylko błogosławiony Szymon z Lipnicy posiada przedstawienia w dziedzinie malarstwa i złotnictwa ukazujące wieloscenowe cykle z jego życia, co jest dowodem aktualności kultu błogosławionego. Należy także pamiętać, że w kościele Bernardynów doszły do głosu wątki aktualne. Dowodem na to jest wzniesienie przy budowie nowego kościoła w 2 poł. XVII wieku wspomnianej kaplicy Św. Anny Samotrzeć. Przypomnijmy, że kult Św. Anny rozwijał się głównie w Warszawie i Krakowie już od 2 poł. XVI wieku.

Szkicując wątki treściowe zobrazowane w sztuce kościoła i klasztoru Bernardynów pragnę przypomnieć, że z krakowskich świątyń barokowych lub w baroku przebudowanych, tylko kościół ŚŚ. Piotra i Pawła oraz do pewnego stopnia Misjonarzy na Stradomiu i kościół Paulinów na Skałce (praca jeszcze nie jest opublikowana), posiadają omówienie zobrazowanych w świątyniach tematów ikonograficznych, które sam przygotowałem. Nawet kościół Mariacki i katedra na Wawelu nie posiadają opracowań, jakiego rodzaju wątki tam obrazowano $\mathrm{i}$ jak te wątki zmieniały się w czasach baroku. 
Pragnę dodać, że w Katalogu Zabytków, w którym omówiono kościół i klasztor Bernardynów udało mi się opublikować 327 ilustracji jego zabytków. Przykładowo w pożytecznej skądinąd książce „Skarby krakowskich klasztorów" obejmującej 7 sponad 100 zespołów (o czym nie mówi tytuł pracy), opublikowano, wprawdzie barwnych, co należy pochwalić, ale tylko 30 ilustracji.

Jako rodzaj addendy zacytujemy Katalog Zabytków Sztuki w Polsce: „Przed kościołem od wsch. obszerny plac, pierwotnie cmentarz kustodialny, wokół którego 1734, staraniem ks. Augustyna Obrąpalskiego, po uporządkowaniu, umieszczono rzeźbione stacje Męki Pańskiej pod drewnianymi podcieniami (do Drogi Krzyżowej włączone były ołtarze w transepcie kościoła). 1743 cmentarz ten powiększono od wsch. staraniem ks. Tomasza Glatza, a podcienia zastapiono murowanym krużgankiem nakrytym dachem. W $1766 \mathrm{r}$. w związku z budową ozdobnej bramy od ul. Stradom zawarto kontrakt z kamieniarzem Franciszkiem Czwierzewiczem „według danego sobie abrysu na sztuki kamienne" i snycerzem Mateuszem Szepsem na wykonanie siedmiu posagów kamiennym oraz z Wojciechem Trepkowskim na roboty stolarskie; prace ukończono w 1767. W tym też czasie wzniesiono mur od nowej bramy do furty klasztornej. Do pierwotnego założenia należy kamienna figura N.P. Marii Niepokalanie Poczętej, rokokowa po 1734 r., ozdobiona polichromia 1743 r., umieszczona na stojącej na postumencie kolumnie, restaurowana $1849,1881$. Plac uporządkowano i wzniesiono balustradę od ul. Bernardyńskiej 1935, według planów inżyniera Karola Tchurzewskiego".

Wybrana literatura przedmiotu:

Dobrowolski T., Nowoczesne malarstwo polskie, t. 1-2, Wrocław-Kraków 1957, 1960, t. 3 Wrocław-Warszawa-Kraków 1964.

Dobrowolski T., Sztuka Krakowa, Kraków 1978.

Tatarkiewicz W., Dwa baroki, krakowski i wileński, prace KHS VIII 1939-46.

Gustaw R. O., Szymon z Lipnicy, [w:] Hagiografia polska. Slownik bio-bibliograficzny, red. O. R. Gustaw, t. 2, Poznan--Warszawa-Lublin 1972.

Kantak K., Bernardyni Polscy, t. 1-2, Lwów 1936.

Kantak K, Szablowski J., Żarnecki J., Kościót i klasztor ojców bernardynów w Krakowie, Bibl. Krak. 96, 1938.

Kłębowski J., Ze studiów nad sztukq Wita Stwosza. Święta Anna Samotrzecia, [w:] Zeszyty Naukowe Uniwersytetu im. A. Mickiewicza, Historia sztuki, zeszyt 1, Poznań 1959.

Samek J., Krakowskie modele architektoniczne (do zagadnienia warsztatu artysty w sztuce polskiej czasów nowożytnych), Teka Kom. Urban. i Archit., XVI 1982 [model ołtarza].

Samek J., Lekszycki Franciszek (około 1668), PSB t. 17, 1972.

Szablowski J., Ze studiów nad ikonografía śmierci w malarstwie polskim siedemnastego wieku, „Przegl. Powsz.”, 1. 1:1934 i odb.

Wyczawski H. E., Katalog archiwum prowincji ojców bernardynów, Archiwa, biblioteki i muzea kościelne 3-6, 1961-1963. 


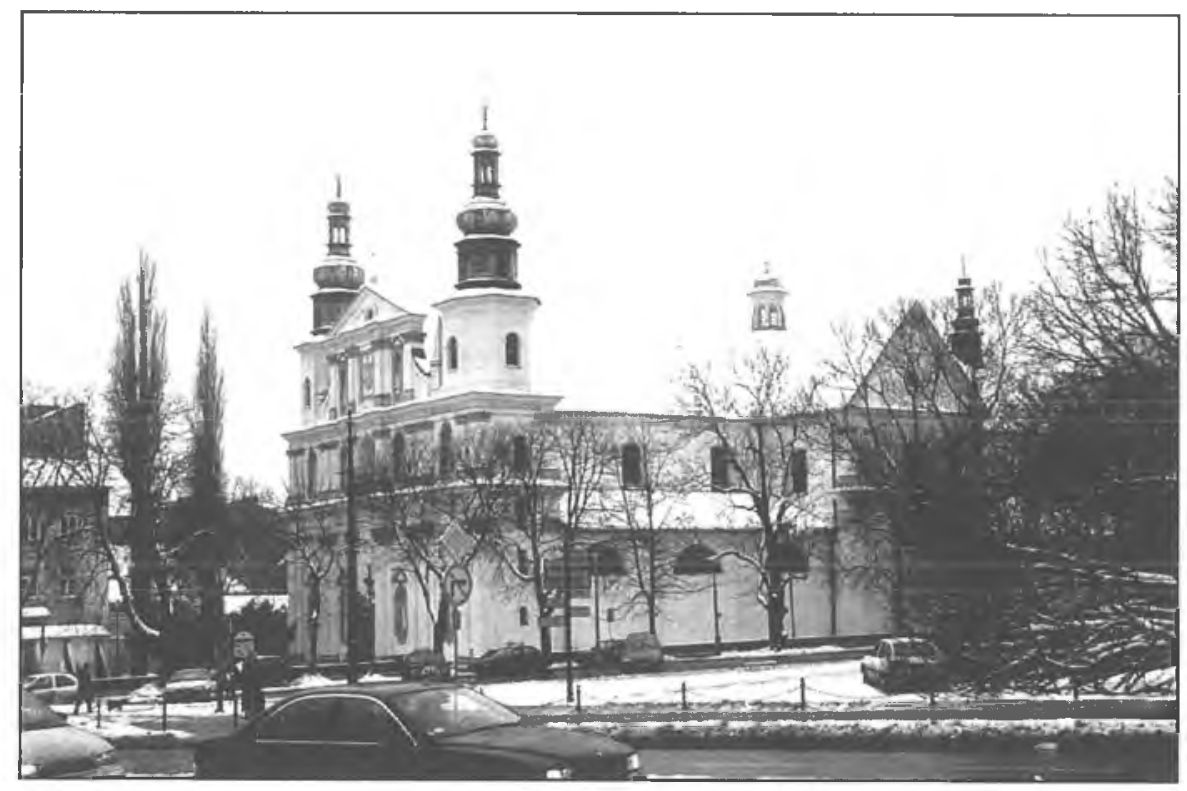

1. Kościół Bernardynów, widok od fasady.

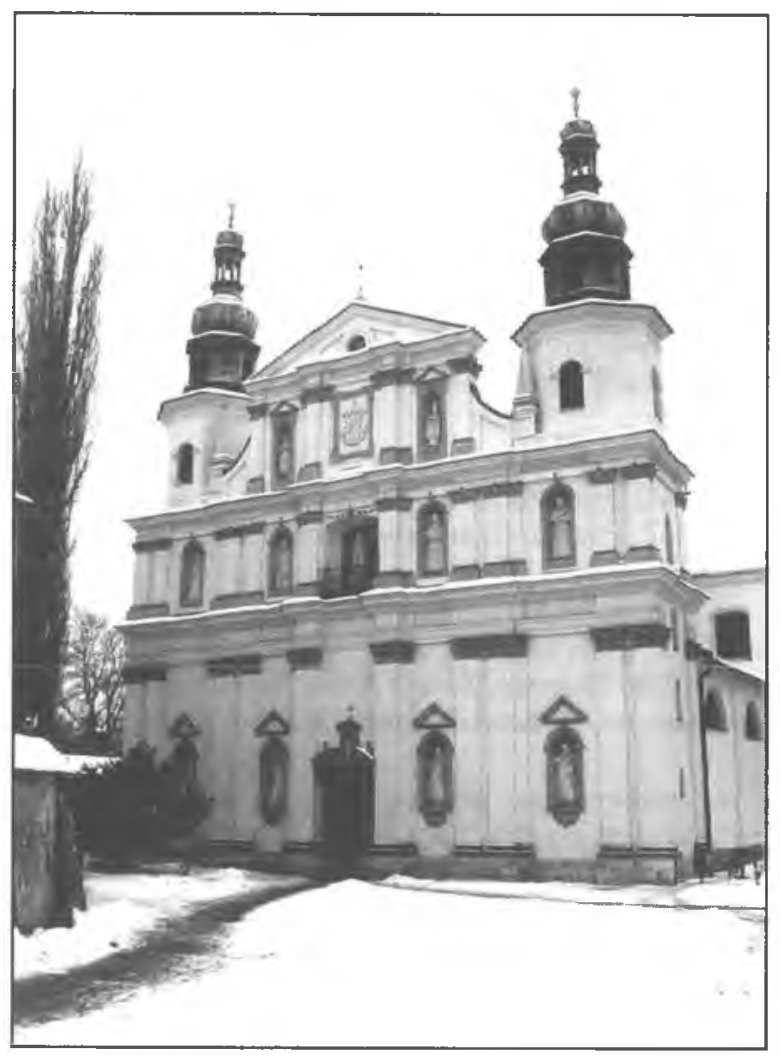

2. Kościół Bernardynów, widok od pn.-wsch. 


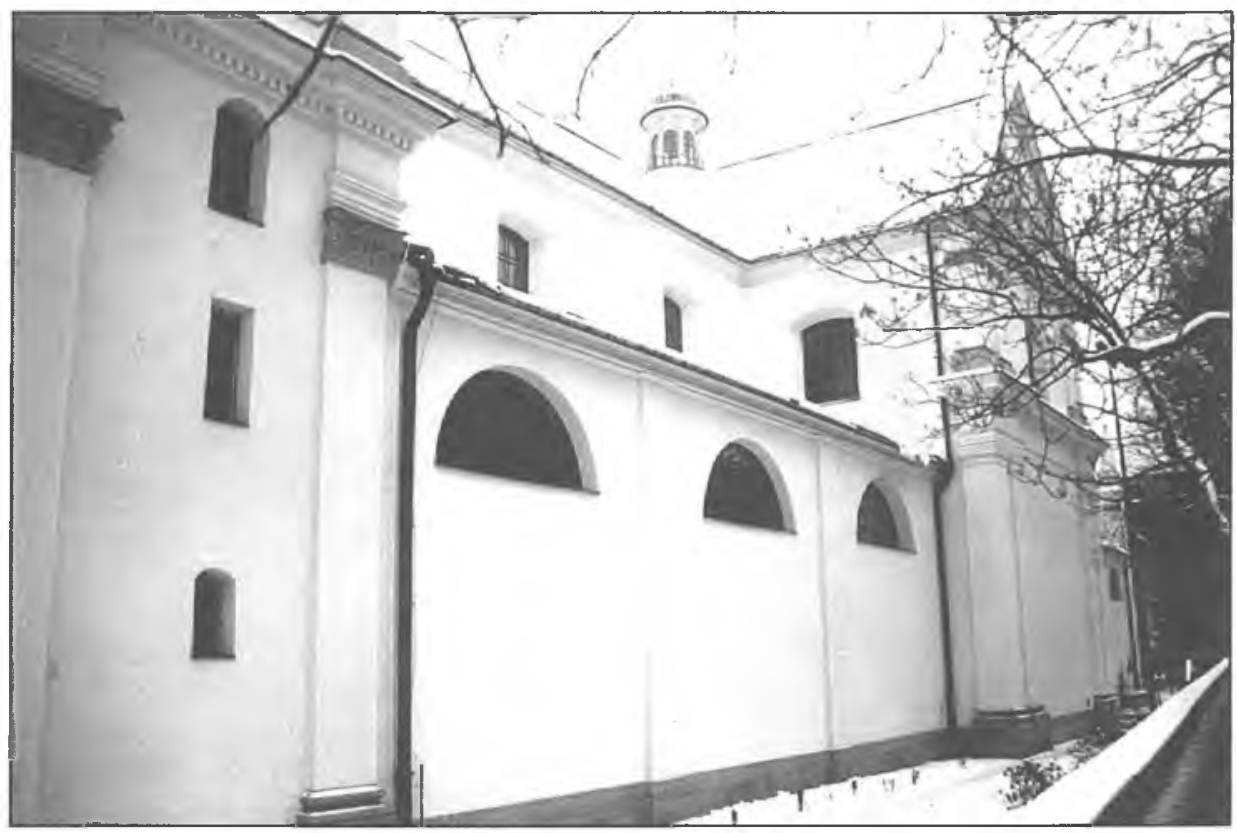

3. Kościół Bernardynów, widok od pn.-wsch.

4. Latarnia kopuły kościoła Bernardynów.

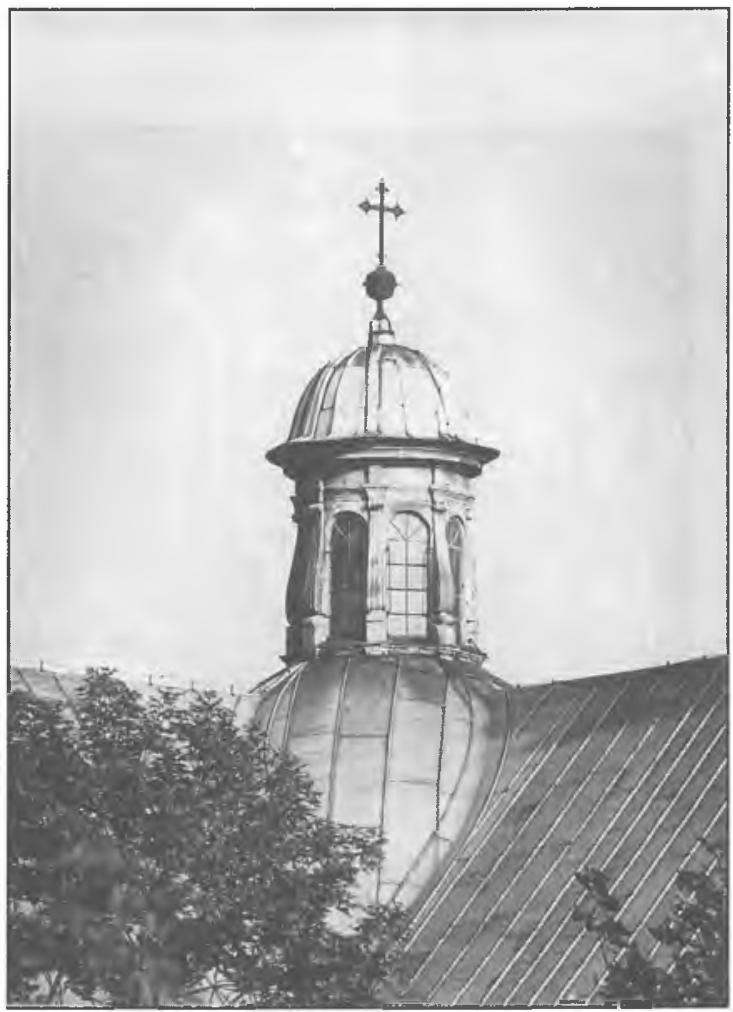




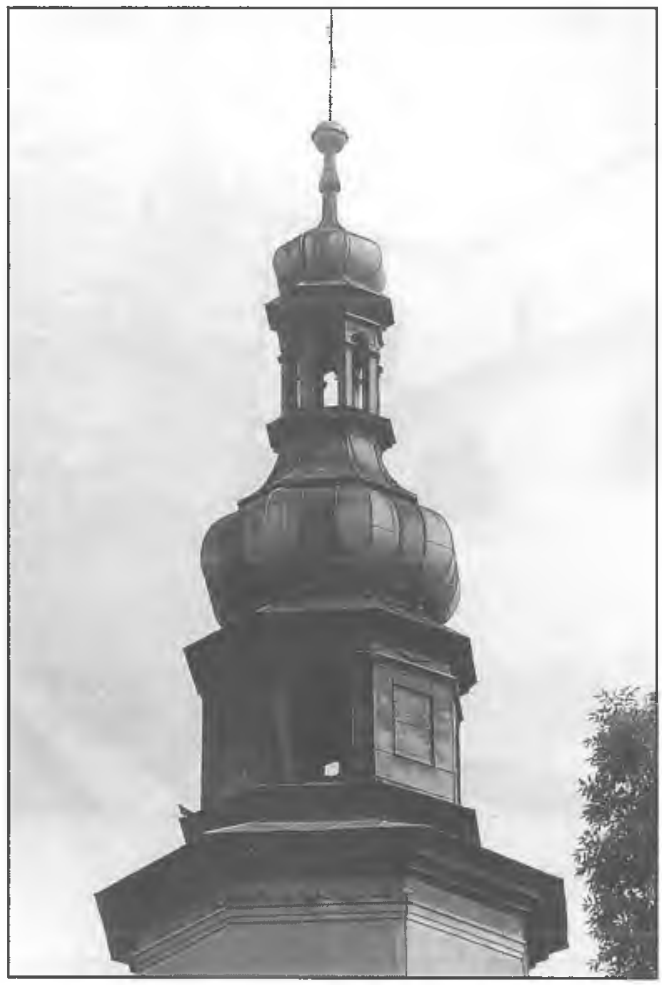

5. Górna część wieży kościoła Bernardynów.

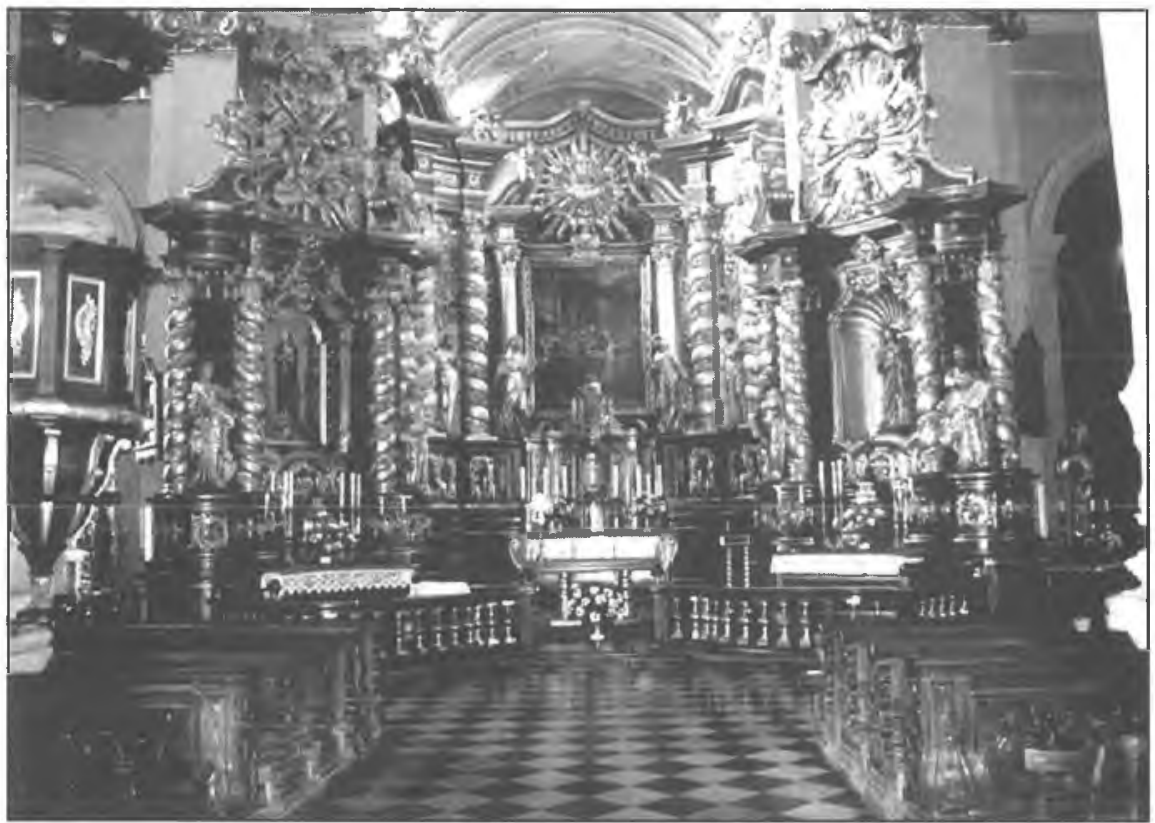

6. Kościół Bernardynów, wnętrze. 
7. Kościół Bernardynów, wnę-

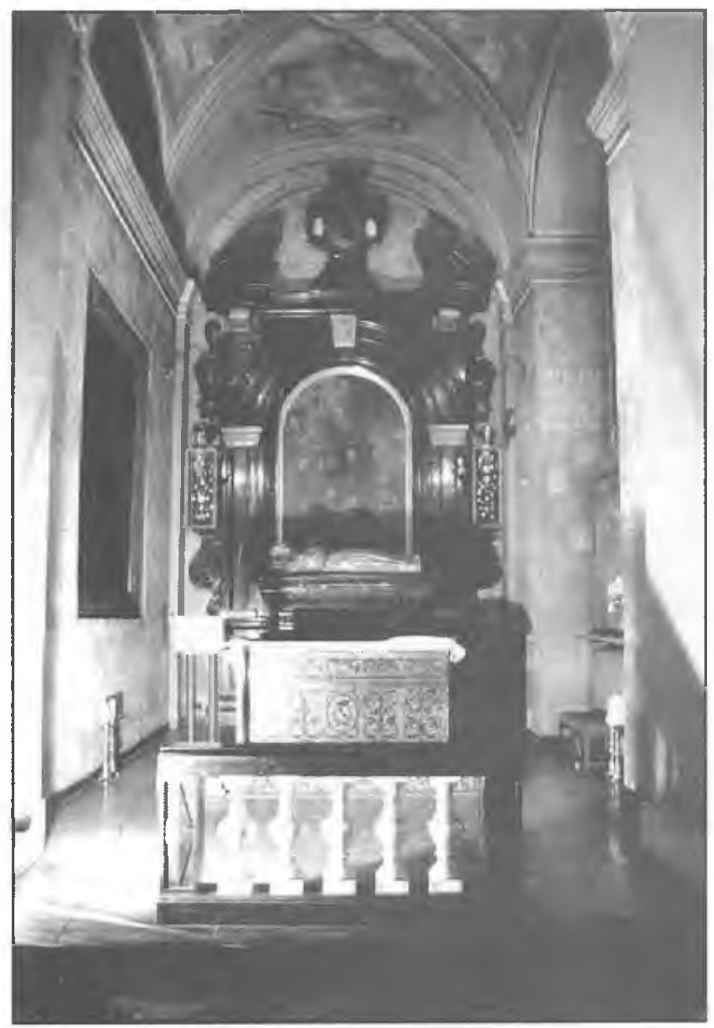

rze.

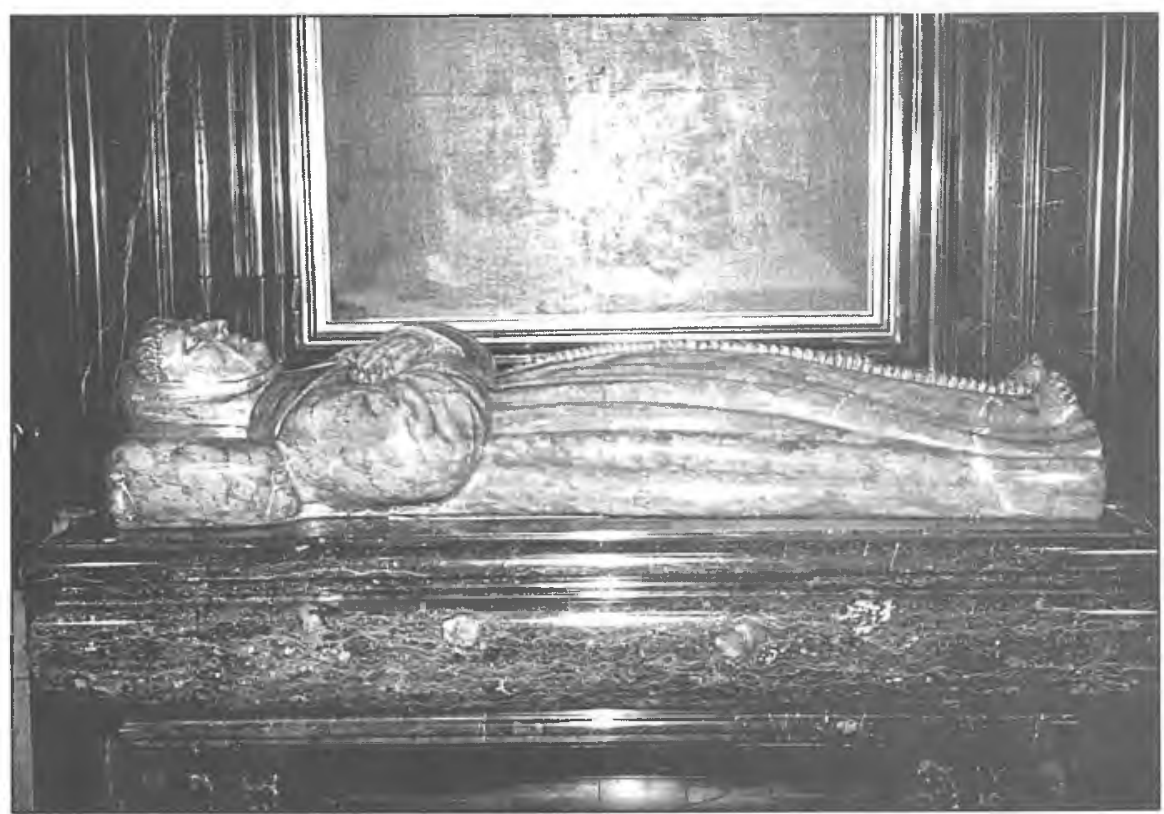

8. Nagrobek bł. Szymona z Lipnicy w kaplicy bł. Szymona. 


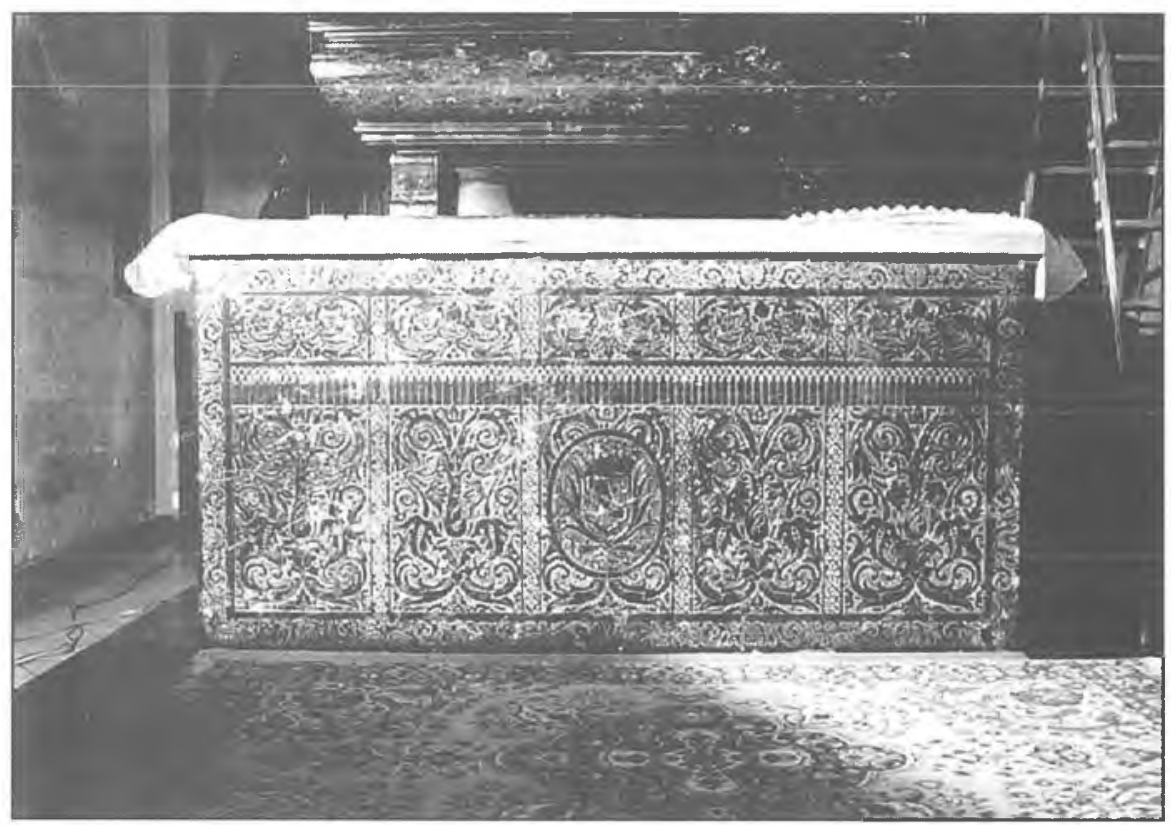

9. Antependium ołtarza w kaplicy bł. Szymona z Lipnicy

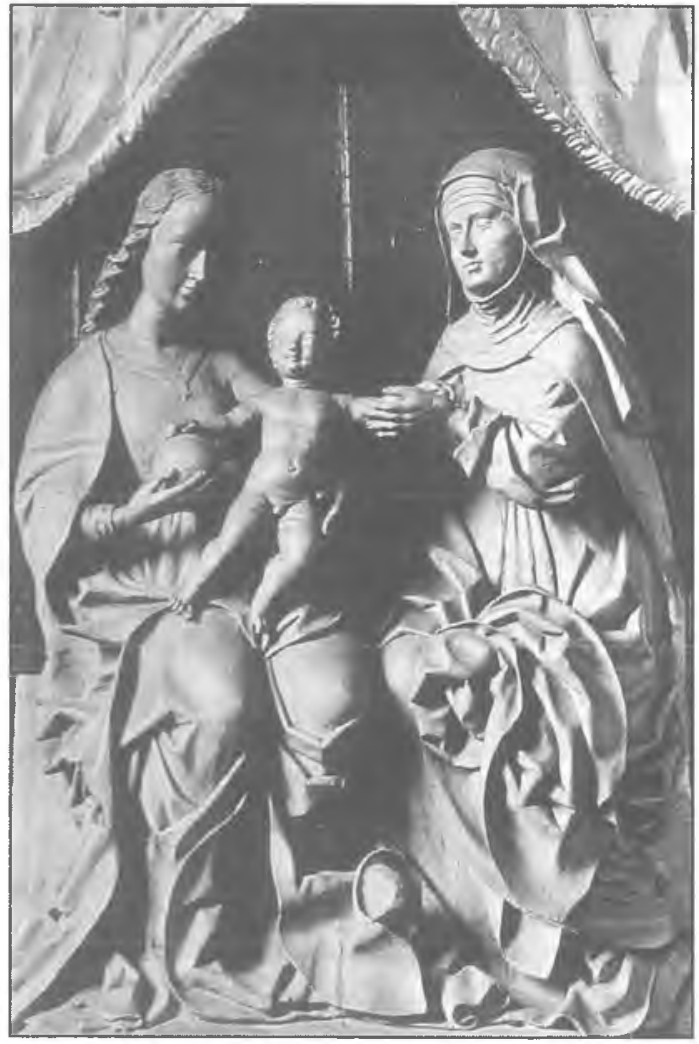

10. Posag Św. Anny Samotrzeć w kościele Bernardynów, koniec $\mathrm{XV}$ wieku. 


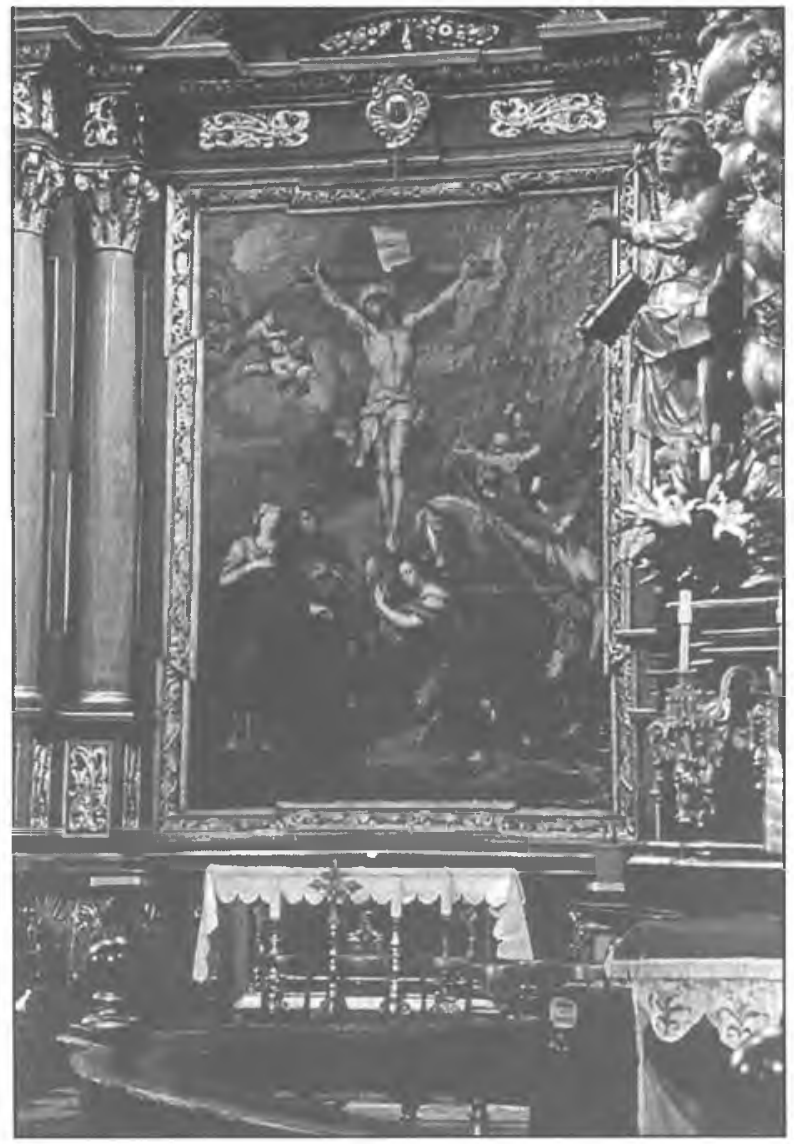

11. Część środkowa ołtarza z obrazem Ukrzyżowanie w kościele Bernardynów, ok. 1659-1664. 


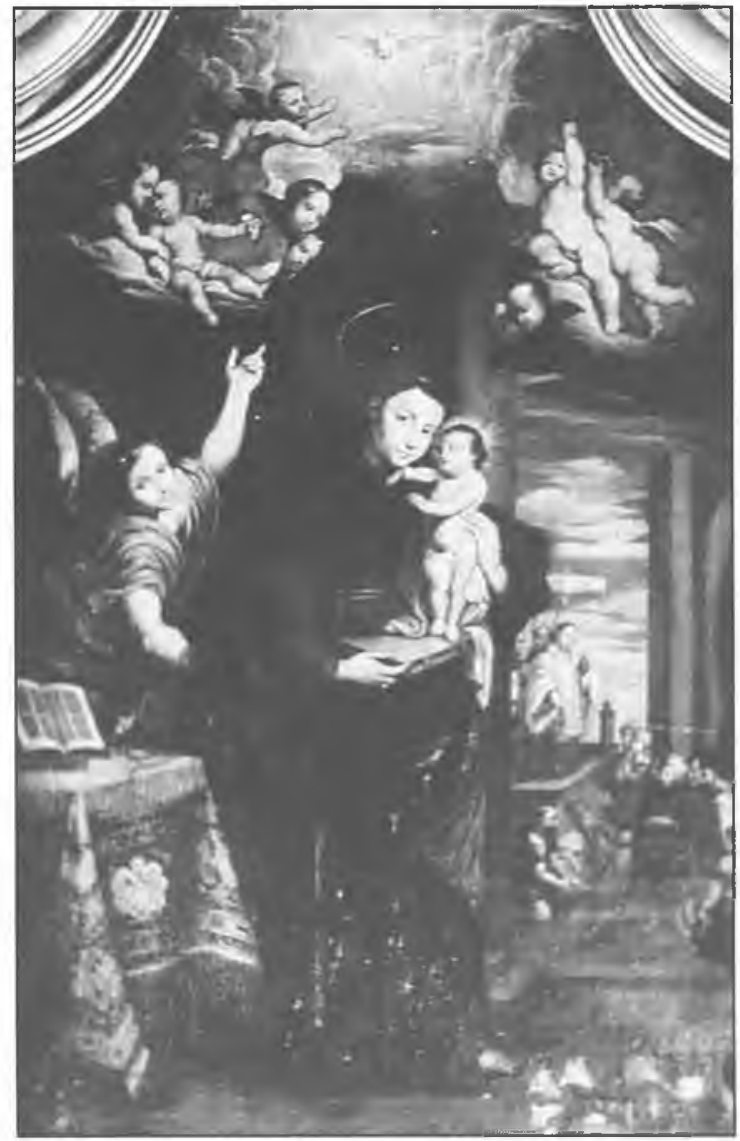

12. Obraz w oltarzu bocznym z wizerunkiem św. Antoniego. 


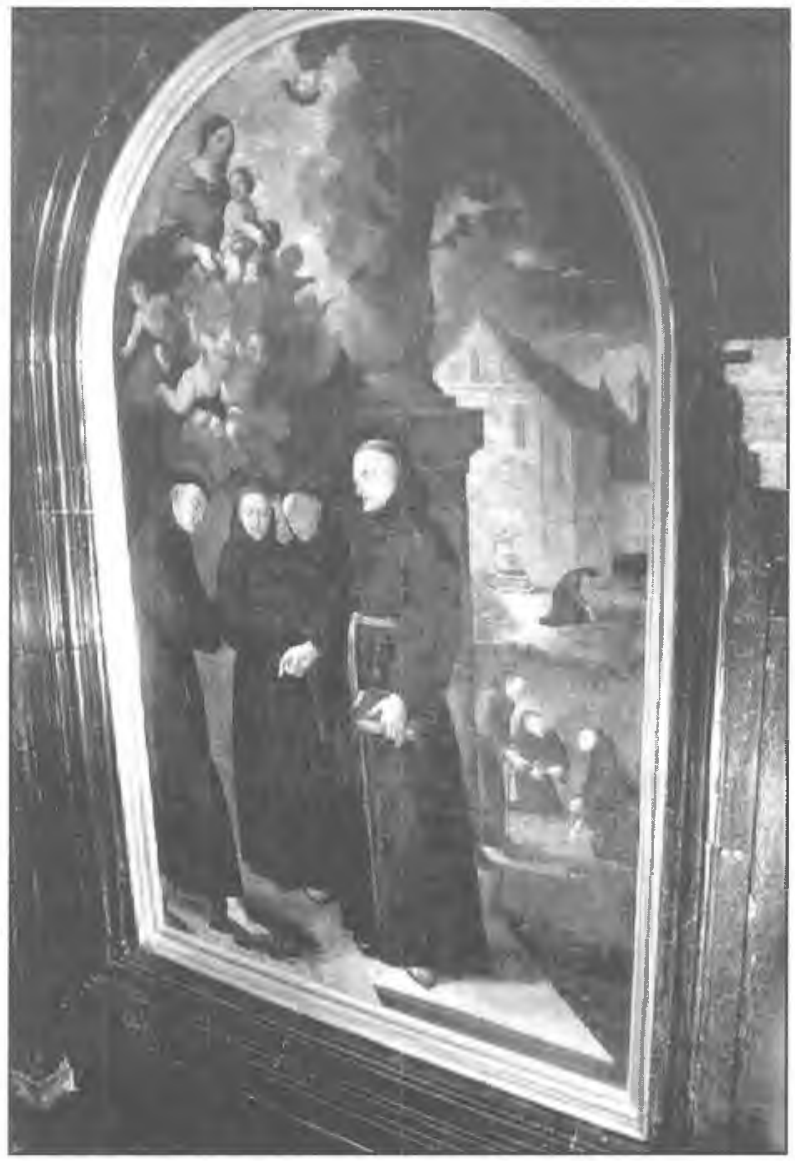

13. Obraz z końca XVII wieku. 


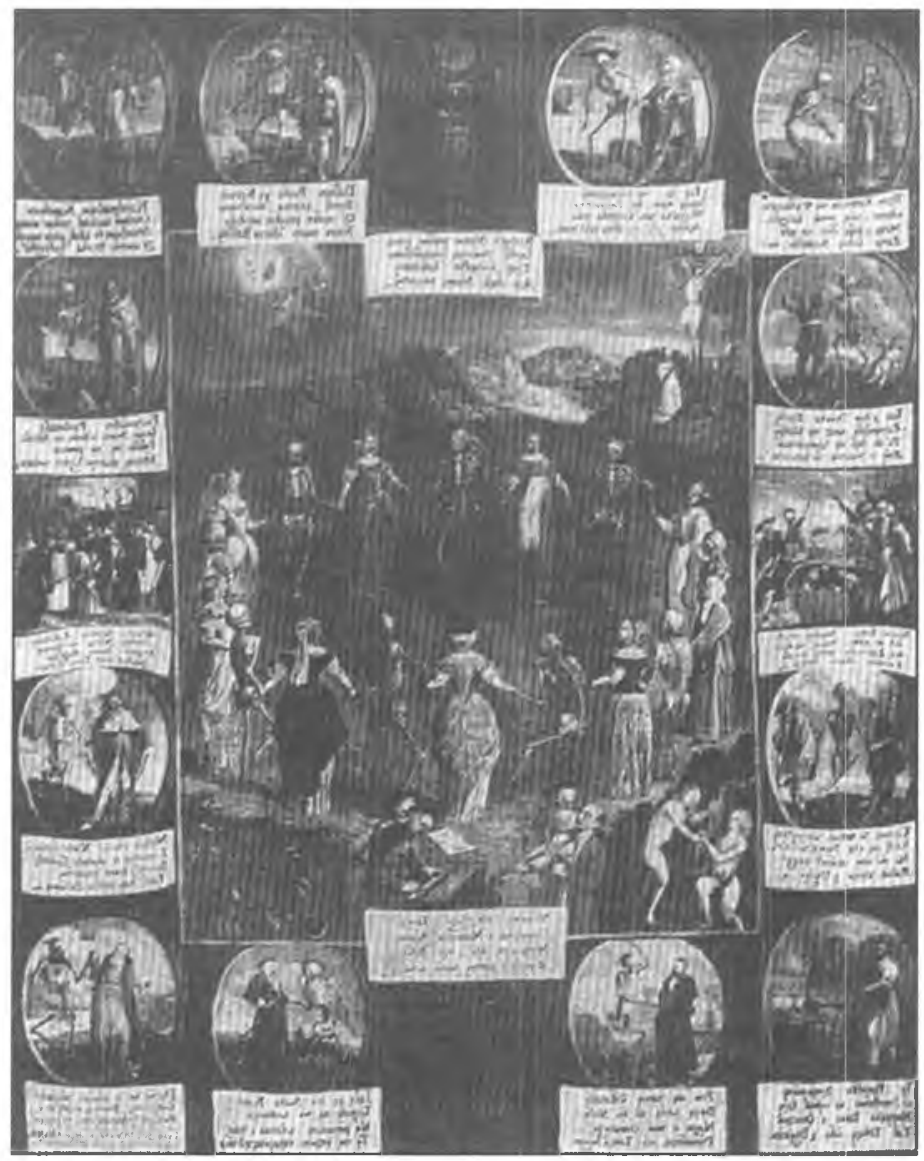

14. Obraz „Taniec śmierci” w kościele Bernardynów. 


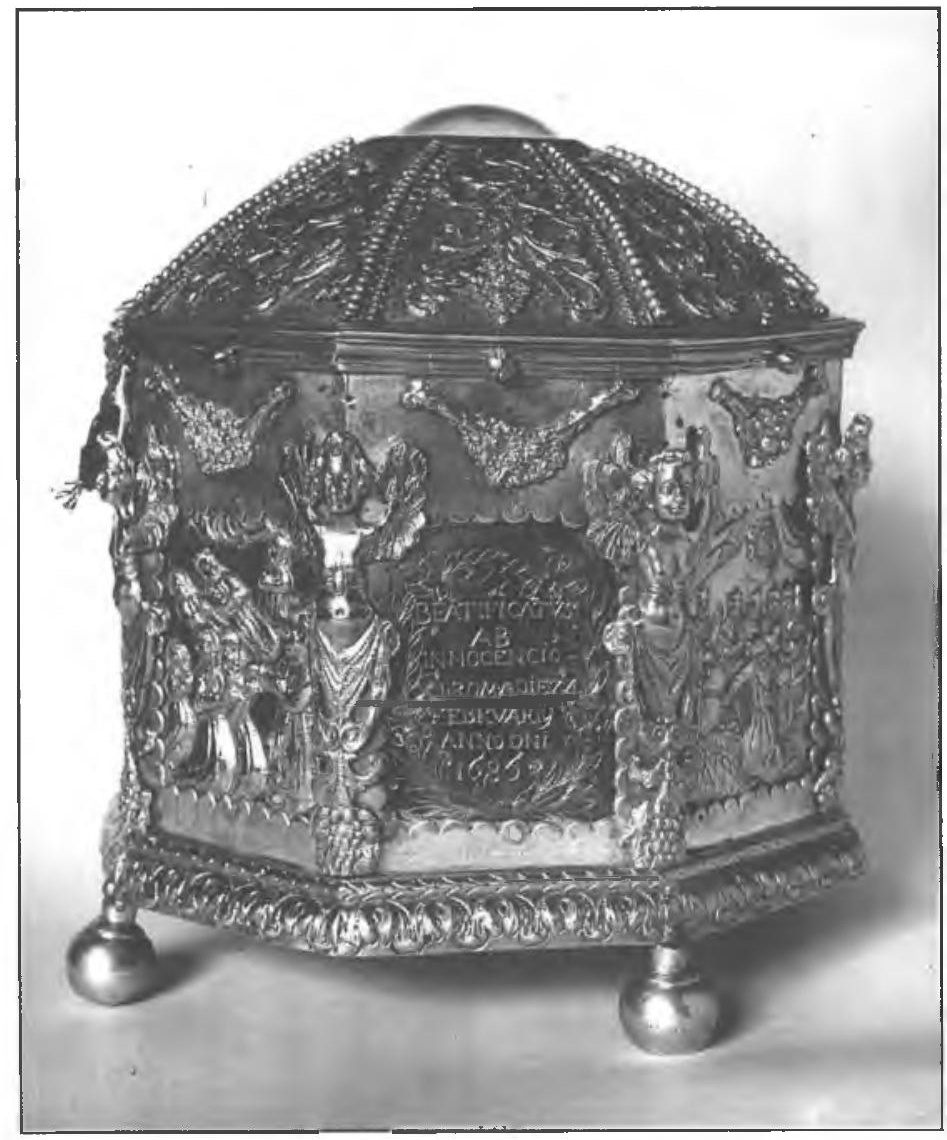

15. Relikwiarz na głowę bł. Szymona z Lipnicy w klasztorze Bernardynów, sprzed 1686 roku. 


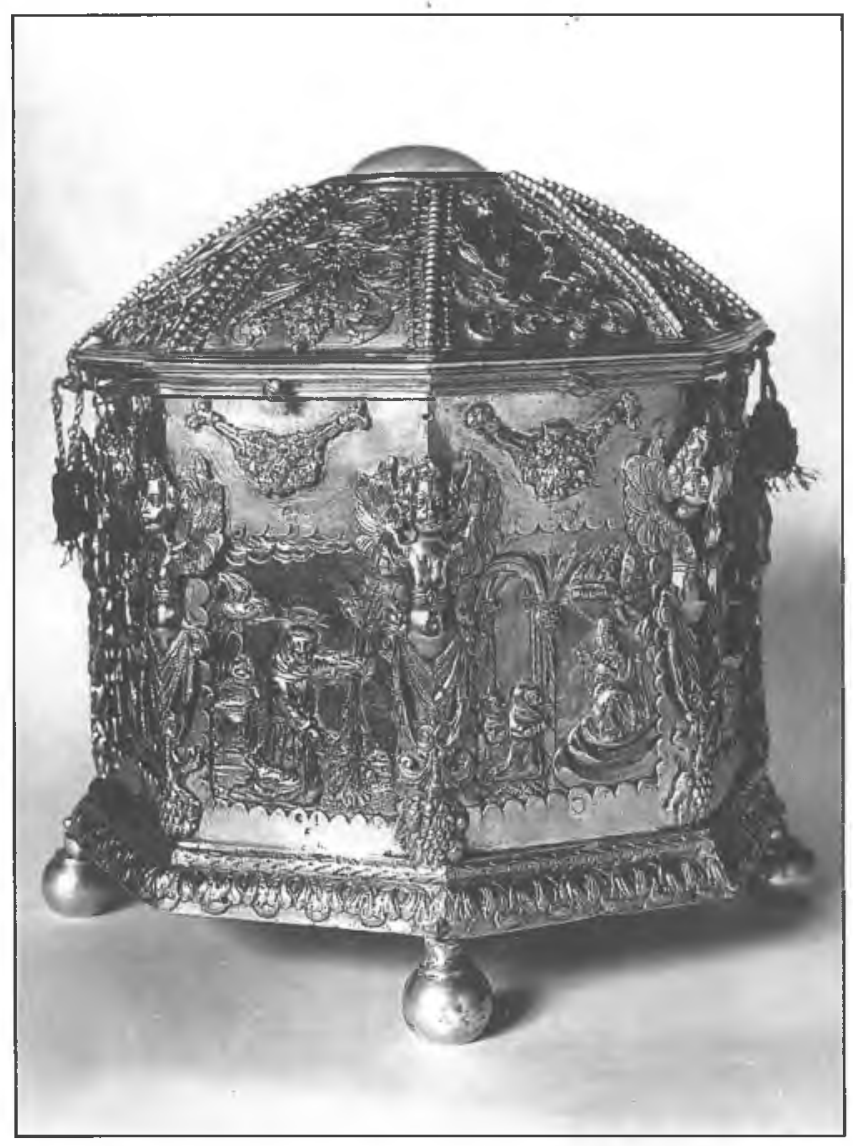

16. Relikwiarz na głowę bł. Szymona z Lipnicy w klasztorze Bernardynów, $z$ przed 1686 roku. 


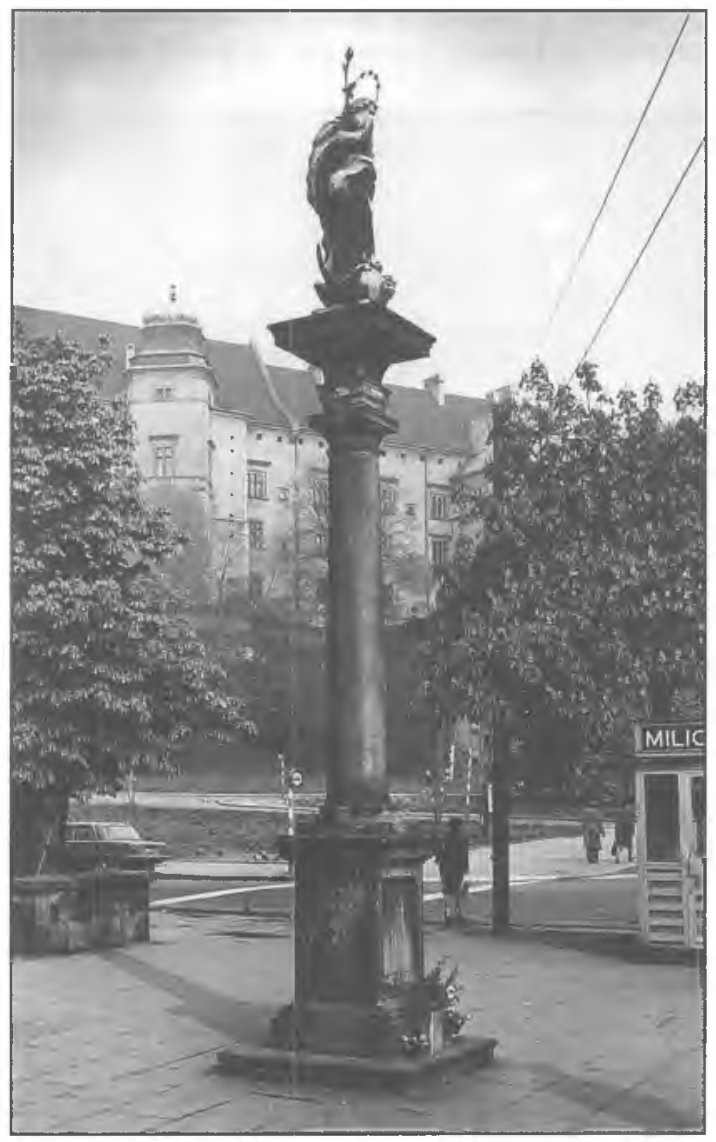

17. Kolumna z figurą N. P. Maryi Niepokalanie Poczętej, po 1734 roku. 


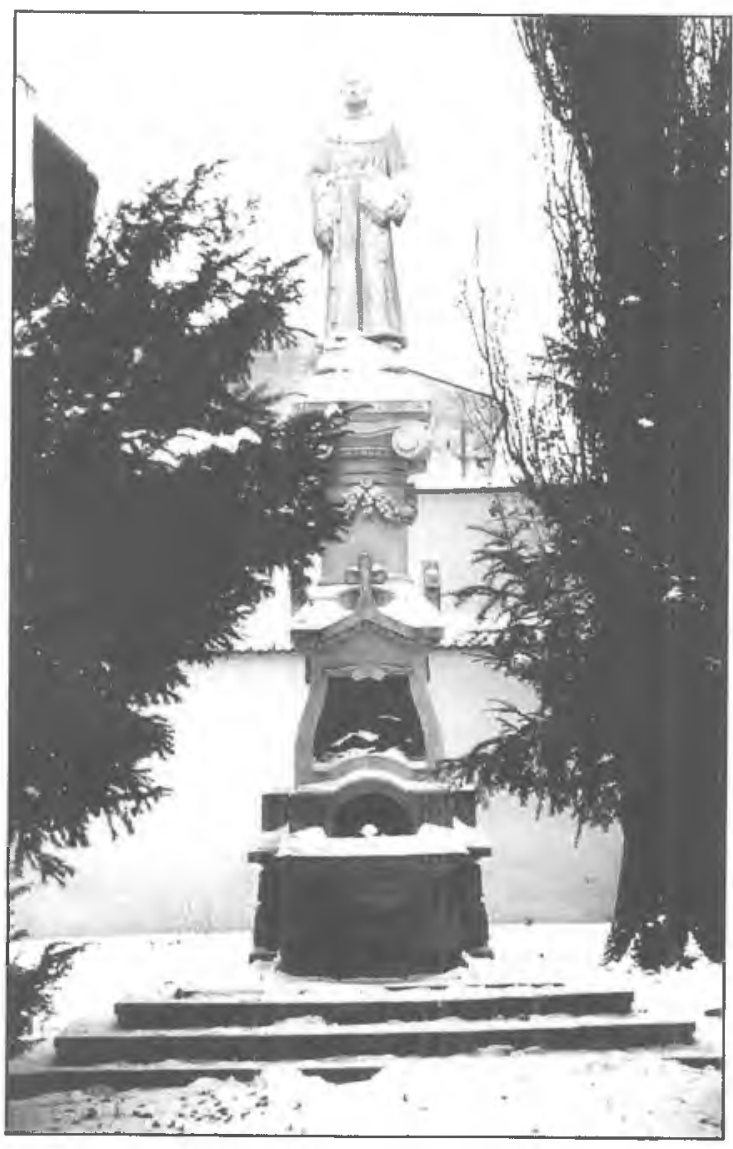

18. „Pomnik” bł. Szymona z Lipnicy. 


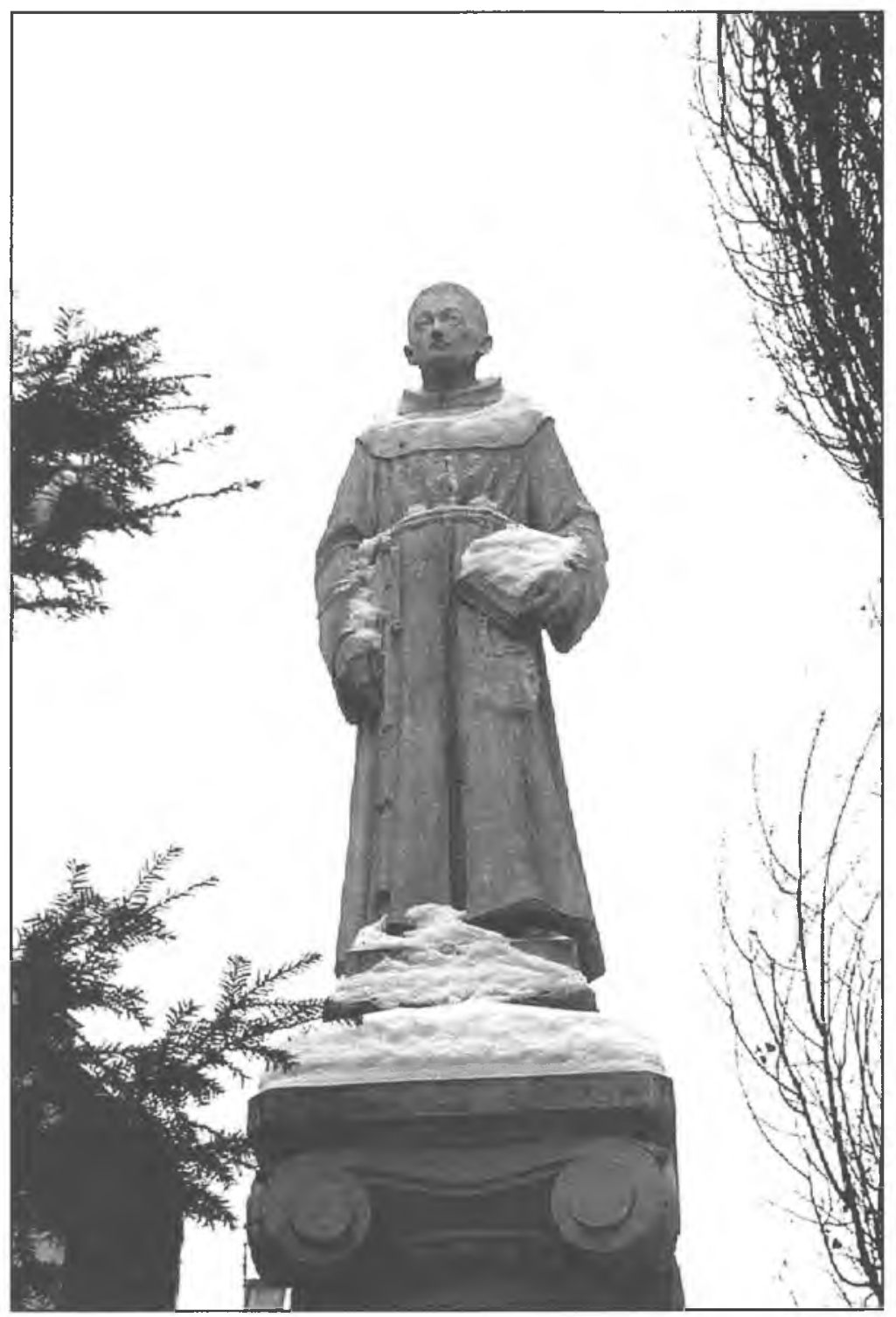

19. Posąg $z$, pomnika” bł. Szymona z Lipnicy. 